\title{
KENYA's 2007 ELECTIONS: DERAILING DEMOCRACY THROUGH ETHNO-REGIONAL VIOLENCE
}

\author{
Rok Ajulu
}

Rok Ajulu is Professor of Political Economy and Head of the Postgraduate Diploma course in International Relation and Diplomacy, University of South Africa e-mail: ajular@unisa.ac.za

\begin{abstract}
The outcome of Kenya's 2007 general elections exposed the soft underbelly of the Kenyan political economy. A country that, until 28 December 2007 , seemed built on a solid foundation suddenly collapsed into warring ethnic constituencies, and revealed the fragile foundations upon which the post-colonial Kenyan state was built. Kibaki's decision to steal the 2007 presidential election resulted in a spiral of violence unlike any in Kenya in 44 years of political independence. In less than one month more than 1000 people died in gruesome ethnic clashes and another 300000 were displaced. Since then, commentators, scholars and analysts have sought to understand why such gruesome acts of violence could actually take place in what has traditionally been considered an oasis of peace in an otherwise conflict prone region. What went wrong? Why did Mwai Kibaki refuse to concede defeat, and instead opt for a semi-secret swearing in at a private ceremony at State House, disregarding the public ceremony for which the armed forces had been preparing? Why did the electoral commission, supposedly an independent body, fail to follow its own due processes? And how do we explain the violent reaction to Kibaki's illegitimate extension of his incumbency?
\end{abstract}

\section{INTRODUCTION}

This paper offers an explanation for the recent Kenyan electoral crisis by attempting to provide answers to the questions posed above. I suggest that the spiral of violence that erupted in response to Kibaki's theft of the 2007 election was a symptom of a much deeper crisis in Kenya's political economy, reflecting, 
as it were, deep-seated frustrations rooted in the socio-economic injustices of landlessness, joblessness and poverty that have beset the country since independence.

I suggest, further, that the crisis of democratisation in post-colonial societies, and in Kenya in particular, revolve around the character of the state and how, historically, it has been deployed by various political classes. The state in postcolonial Kenya has predominantly been deployed as a 'site of eating', that is, state power has been used to secure the economic interests of the dominant political classes and to enable them to dispense patronage and political manna to their client base, almost invariably, ethnic-based constituencies. Such a state invariably appropriates state institutions and deploys them as instruments of primitive accumulation, pursuing policies and objectives which conflict with broader society interests. In the context of uneven capitalist penetration in Kenya and its tendency to engender regional (ethnic) inequalities, such contestation is bound to engender regional (ethnic) disparities which are then expressed as ethnic contests.

Thus we can argue that the ethnic clashes which have characterised much of the period of multiparty politics are not tribal conflicts in the real sense, rather, they are politically organised conflicts orchestrated to achieve short- and long-term political, and ultimately economic, advantages. I propose that an understanding of the recent electoral crisis in Kenya must be sought within an analysis that confronts the nature of political economy, forms of accumulation and the way these have informed the conduct of politics itself.

The paper is structured as follows: the introduction is followed by a brief historical sketch of the rise of authoritarian governance and institutionalised despotism in Kenya's post-colony. The third section analyses the Kibaki/ National Rainbow Coalition (NARC) regime since 2002 and the political developments leading to the 2007 elections. This section is followed by a focus on the election and its outcome, on which is based an explanation of the violence. The conclusion attempts to draw the narrative together.

\section{INSTITUTIONALISED DESPOTISM: KENYATTA AND MOI}

\section{The Kenyatta regime}

Kenya became independent in 1963, governed by a Westminster parliamentary system involving the Kenya African National Union (Kanu) and the Kenya African Democratic Union (Kadu). Kanu had won the majority of seats in the bicameral Assembly and had formed the first independent government, while Kadu settled in the opposition benches. 
The two parties had represented different combinations of class forces. Kanu was the party of sections of the indigenous embryonic capitalist class, the petit bourgeoisie and aspirant African middle classes, which, for historical reasons, consisted mainly of the Kikuyu and Luo ethnic groups. Kadu was also included in a convoluted alliance with unlikely bedfellows - a trade union movement, the Kenya Federation of Labour; the urban working class; urban traders; the Nairobi Crowd ${ }^{1}$ (Furedi 1973); the peasantry; and, more significantly, the squatter movement, which was predominantly, but not exclusively, Kikuyu. The battle between these different class forces over the post-colonial state would result, in 1966, in a split and, eventually, in the ethnicisation of political discourse and descent into authoritarian rule.

Kadu on the other hand, was an alliance of the weaker sections of similar class forces, mainly from the minority nationalities - the Nilotic ethnic groups in the Rift Valley, which call themselves the Kalenjin, sections of the Luhyia tribal groupings, and the coastal Giriamas and Swahilis of Arabic extraction (Njonjo 1977). This party lacked the political clout to compete on an equal footing in the then unfolding political space. Not surprisingly, its political programme was underpinned by the demand for majimboism (federalism).

On the first anniversary of independence, in December 1964, Kenya became a republic, with Jomo Kenyatta its first president and Jaramogi Oginga Odinga, a member of the radical wing of the party, his deputy. At the same time Kadu defections to the ruling party, which had started in 1963 with the defection of Nandi MP Jean Marie Seroney, now turned into a full-scale desertion. The result was that Kadu dissolved itself and joined the ruling Kanu, creating a de facto single-party system. This move bolstered the conservative faction within Kanu and created an environment in which the long-running ideological battle between the radicals and the conservatives in the ruling party could now be fought to its conclusion

The battle finally led to Vice-President Odinga and veteran trade unionist Bildad Kaggia breaking with Kanu in 1966 to form the opposition Kenya People's Union (KPU). The formation of the party was the culmination of a protracted battle over ideological differences which had consumed the party throughout the six years of its existence (Odinga 1966). Odinga and Kaggia were followed onto the opposition benches by 33 members of Parliament. The establishment of the opposition and the return of multiparty politics confronted the Kenyatta regime with its first serious political crisis and, in the end, exposed the authoritarian nature of the regime. The government rushed through new legislation, Amendment 2 of

1 Furedi uses the concept 'crowd' to define the urban classes which had the smallest stake in the colonial political economy. The 'crowd', like the 'sanscullote' of the French Revolution, had a limited stake in the status quo. 
Act 17 of 1966, the Fifth Amendment to the Constitution, which required that all members of the Assembly who changed parties must seek a new mandate from their constituencies (Gertzel, Goldschmidt \& Rothschild 1969).

In the 'little general election' which followed the resignation of the KPU members, Kanu won eight of the ten Senate seats to KPU's two and 12 of the 19 House seats to KPU's seven. The KPU's strength was thus reduced to Odinga's Nyanza constituency, and it was now perceived as a tribal party. This ethnicisation of the opposition party suited the ruling party and the government perfectly. Mueller (1984), however, suggests that the KPU's national presence was much stronger than its Nyanza representation might have suggested and that the state's use of repressive tools against the party may explain its eventual demise.

Kenyatta's second political crisis came in the wake of the assassination of Tom Mboya in 1969, at a time of increasing resentment of the consolidation of Kikuyu power in the economic and political spheres. At the forefront of this resentment was the Luo community, who felt marginalised in the distribution of state resources. Mboya might have remained within the Kenyatta coalition, and had been instrumental in forcing Odinga out of Kanu and government, but he retained substantial support among the Luo and, in certain quarters, was regarded as the only surviving Luo link with the government (Goldsworthy 1982). His ambition to succeed Kenyatta struck a favourable chord within certain quarters in Luoland who argued that it was not in the interest of Luos to put all their eggs in the KPU basket.

Within this context the outpouring of anger that followed his assassination in a Nairobi street can be understood. The demonstrations were largely spearheaded by the Luo community, but they nonetheless incorporated large elements of other groups within the urban areas. Nairobi, the capital, was rendered ungovernable for almost a week. Similar demonstrations took place in Mombasa and Nakuru and in Homa Bay, Mboya's home town.

The regime was shaken by Mboya's assassination as it had not been by the formation of the KPU. The resignation of a deputy president from government was, after all, part of the normal knock about of politics; the assassination of a senior minister, ruling party secretary-general and a leading contender for the presidency was an entirely different ball game. It damaged the country internationally and, more significantly, it fundamentally eroded the legitimacy of Kenyatta and his regime.

Kenyatta's response to the political challenge posed by the Mboya crisis was to invoke narrow national chauvinism and seek cover under Kikuyu ethnicity. The government organised and orchestrated an 'oathing' campaign to mobilise the Kikuyu peasantry and the Kikuyu urban sansculottes behind the Kenyatta regime. The oathings were conducted mainly by Kikuyu officials of the provincial 
administration at Gatundu, Kenyatta's Kiambu home. The oaths were designed to unite the Kikuyu ethnic group in a determination to keep the 'flag in the house of Mumbi' (Karimi \& Ochieng 1980), that is, the government to remain under Kikuyu leadership.

Kenyatta's third political crisis emanated from the assassination of the populist Nyandarua North MP and former assistant minister J M Kariuki (popularly known as JM). JM's sin, it would seem, was threefold. He was a 'Diaspora' (Rift Valley) Kikuyu whose parents, like most landless Kikuyus at the beginning of the 20th century, had migrated to Rift Valley. He had been a member of the Mau Mau movement and had been detained and was therefore not part of Kenyatta's Kiambu coalition, which held a stranglehold on political and economic institutions of the state.

Secondly, he had accumulated wealth in the first six years of independence and had used it to champion populist Kikuyu and national causes and to position himself for the Kenyatta succession. By 1973, he had built a strong populist following in the two Kikuyu districts of Nyeri and Muranga and counted among his followers such Kikuyu heavyweights as Waruru Kanja from Nyeri and Charles Rubia from Muranga.

Third, JM transcended his ethnic base and, by appealing for redistribution of land, was able to put together a populist platform nationally. Among his followers were the MP for Tinderet, the deputy speaker of the House, and several assistant ministers. As a Kikuyu he was capable of subverting Kikuyu sub-nationalism from within (Throup 1989) and thus posed the most serious political threat to the Kenyatta coalition.

What do we make of this brief summary of the Kenyatta regime? Even though Kenyatta presided over a growing economy and an expanding middle class, and allowed a small political space within which parliamentarians could make a few noises, it would seem that the most visible trademark of his regime was its refusal to accept democratic challenges to its right to rule.

From 1969 the regime displayed a growing arrogance in the use of state power for the purpose of personal accumulation and completely politicised the allocation of public resources. This predictably facilitated the consolidation of the indigenous class of capital and property, which, for historical reasons, had emerged predominantly from within the Kikuyu, particularly the powerful Kiambu faction, which directly controlled state power.

This period thus produced a more cohesive 'lootocracy', the Kiambu section of the economic elite constituting its inner cabal, and the rest, arranged in its respective pecking order. In the dying days of the Kenyatta regime, deliberate politicisation of the allocation of public resources, particularly to Kenyatta's Kiambu coalition, was clearly visible. By 1978 a powerful politico-economic class 
had emerged within this group and dominated the economy and politics. It had effectively moved from traditional areas of primitive accumulation into modern sectors of the economy - manufacturing, banking, and finance.

It is this tight control of economic and political power by a small section of the Kiambu clique that probably explains the euphoria in the early days of Moi's presidency.

\section{THE MOI REGIME AND THE RISE OF THE KLEPTOCRATS}

Moi took over the presidency in 1978, after Kenyatta's death. During his 12 years as vice-president he had observed the growing arrogance of the Kenyatta coalition at close quarters and watched as its members used state power to ascend to the commanding heights of the economy. He must have concluded that political power was more than a Cabinet office, it was the access to the key levers of the economy. But initially he was too weak to break the established Kenyatta coalition, so, in the next five years he ruled through the support of Mwai Kibaki and Charles Njonjo, finance minister and attorney general respectively in the Kenyatta regime.

The failed coup attempt of 1982 was probably the most important turning point in Moi's consolidation of power. It enabled him to dismantle Kenyatta's security apparatus and replace it with his own, though the extent of his success remains debatable. ${ }^{2}$ At the same time he brought back detention without trial, and repression once again became a pillar of political order. Finally, he could now openly assemble a ruling coalition of his own and, once this was in place, could afford to confront Charles Njonjo, Kenyatta's powerful attorney general, who had helped him to ascend the presidency. Within a year of the coup attempt Njonjo had been removed from government and the party and, following a humiliating commission of inquiry, dispatched into the political wilderness.

President Moi's new alliance was, however, a relatively weak economic class, predominantly an alliance of politicians from the areas with the least capitalist development. And, unfortunately, his rule commenced with the doubling of the oil price - which, two years later, was absorbing 50 per cent of foreign exchange earnings - and a massive fall in cash crop earnings. Thus Moi's embryonic accumulators could only assemble a capital base by looting the original looters, or, as Mutahi Ngunyi (1993) puts it, it could only be predicated on the dissolution of the already entrenched Kikuyu capital.

2 Throup 1986, for example, asserts that as late as 1986 Moi had not established hegemony over the armed forces. 
Patronage and resources came to be concentrated in Moi's own ethnic group, the Kalenjin in general, and the Tugen in particular, a process that coincided with the consolidation of his coalition in the aftermath of the coup attempt. Furthermore, Moi, like Kenyatta, politicised the allocation of public and private investments - roads, educational infrastructure, and agricultural investments were directed mainly at Moi's political constituency. The new power thus became self-consciously a Kalenjin power; institutions previously dominated by the Kikuyu were 'Kalenjinised'. Access to resources - university education, state and employment in parastatals - depended on whether one was recognised by the government as a member of the 'Kanu' tribe'.

This type of distribution of resources and the crude use of the state for primitive accumulation could only be predicated on authoritarian control. Thus the deeper it sank into kleptocracy the more authoritarian the state became. Not for nothing did Moi do away with the ethno-regional balancing act that had provided a veneer of political legitimacy and stability for the Kenyatta regime. The substitution in 1987 of the secret ballot system with queue voting was one such indication of the regime's loss of confidence in free and fair electoral contests. More importantly, however, the Moi regime fostered a kleptocratic bourgeoisie whose existence and survival depended very much on its continued access to this type of authoritarian state

\section{FROM KLEPTOCRATS TO PREDATORS}

The reintroduction of competitive elections towards the end of 1991 caused panic and tension within Moi's coalition. Convinced that they were unlikely to win democratically-conducted elections its members set about the serious business of plundering the state, gradually transforming its institutions into predatory instruments of primitive accumulation by a largely parasitic class.

The unmitigated plunder of state resources took different forms - dubious contracts, questionable purchases by government departments and parastatals, unauthorised expenditure, non-payment of duties on imported goods, the award of government lands to cronies and subsequent sales to well connected businesspersons, the sale of government houses to supporters at knockdown prices and the awarding of non-existent consultancies to dubious consultancy firms.

This was the period of the infamous Goldenberg scandal, in which a local firm, Goldenberg International, owned by an Asian businessman, Kamlesh Pattni, was allegedly paid KSh51,5-billion for non-existent gold and diamonds exports.

Such was the prevailing state of affairs when political space opened up and Kanu was replaced by the NARC coalition in 2003. 


\section{ENTER KIBAKI}

Kibaki, representing NARC, became president in 2003 on a wave of popular rejection of Moi's regime and in the most celebrated landslide victory in Kenya's electoral history. NARC was cobbled together by Kibaki's Democratic Party (DP), the late Michael Wamalwa's Ford Kenya (FORD-K), and Raila Odinga's Liberal Democratic Party (LDP).

The DP represented the hegemonic class of capital and property, which had its origins in Kenya's first independent government under Jomo Kenyatta. This was the elite of the old Nyeri bourgeoisie and its Kiambu counterparts (predominantly, but not exclusively, the Kikuyu). This group, now referred to in Kenya's political discourse as the 'Mount Kenya Mafia', remains the most powerful economic class in the country; Kenya's indigenous bourgeoisie par excellence.

While it suffered considerable setbacks under the Moi regime it was not completely wiped out and has a long experience of straddling economic and political power. Significantly, it moved quite speedily to occupy the strategic positions vacated by the Moi crowd.

Raila's LDP and, to some degree, Ford Kenya represented the traditional petit bourgeois leadership of Kenya's opposition. It lacked a firm economic base, was considerably impoverished and because its leaders had been in the political wilderness for a considerable time they had limited experience of wielding political and economic power.

The NARC coalition, far from being born out of a political ideology, was an amalgam of old and new recycled Kanu politicians glued together by common hostility to Moi to form a united front to topple Kanu and gain access to State House. Beyond that, the three major parties in the coalition had very little in common; they were a ragtag army of political opportunists on a journey to selfrenewal. Not surprisingly, their coming together as a coalition had to be spelled out in black and white in the now famous founding document, the Memorandum of Understanding (MoU), which outlined how power and the spoils of victory would be distributed within the coalition.

There is a broad consensus that Kibaki's DP reneged on the MoU's core idea of an equal partnership between the NAK and the LDP; that he failed to consult his partners about Cabinet appointments and other senior positions within the government, and that, in his distribution of the spoils, he ignored key LDP constituencies in the Nyanza, Western and Coast provinces. Furthermore, it is acknowledged that Kibaki's Mount Kenya coalition moved speedily to dispense state patronage to its constituency.

Appointments to senior government positions, parastatals, and diplomatic postings predominantly favoured Kibaki's ethnic group, and Kibaki, like Moi and 
Kenyatta before him, politicised the allocation of public and private investments - the provision of roads, educational infrastructure, and agricultural investments was directed mainly at his political constituency.

The new NARC power similarly became self-consciously a Kikuyu power; institutions previously dominated by the Kalenjin were 'Kikuyunised' and access to resources - employment by the state and in parastatals - depended on whether one was recognised by the government as a member of the Mount Kenya grouping (Mwangi 2008).

Tensions over and disagreements about the MoU were to characterise Kibaki's entire first term and form the backdrop against which the 2007 elections would take place. It is also against this background that the constitution-making process at the National Constitutional Conference (the Bomas Conference) came to play such a central role in the battle for control of the state.

At the centre of the controversy at Bomas had been the whittling away of presidential powers and the creation of an executive premier. Because of the unpopularity of the previous regime there had been a national consensus over these issues and NARC had made them a plank in its campaign platform but it became clear that, having moved into State House and, in a sense, tasted the fruits of political power, the DP faction had no interest in any constitutional reforms which might tamper with the powers of the presidency.

Thus, during the entire NARC regime the country witnessed a macabre battle over the Memorandum of Understanding through the constitutional reform process. It was a battle the Kibaki faction was unlikely to win since delegates to the conference had been appointed by the previous regime and were perceived to be loyalists of the short-lived Kanu-NDP Alliance of former president Moi and Raila Odinga.

The November 2005 constitutional referendum which had divided the ruling NARC coalition into two camps - the Banana camp (Kibaki) and the Orange camp (Raila Odinga) - and in which the government was defeated by the Orange camp, proved to be the culmination of the disintegration of the coalition. The main contentious issue was how much power should be vested in the presidency and how other political institutions might be strengthened.

Because President Kibaki had vigorously supported the new Constitution and was perceived to be attempting to entrench an authoritarian presidency many voters used the referendum as a vote of no confidence in the president. The victory of the LDP faction and its expulsion from government set the stage for the 2007 general elections and, for all practical purposes, election campaigns started in earnest at the end of the referendum.

In the run up to the elections Kibaki made two decisions with farreaching implications for their outcome. First he brushed aside the Inter Parties 
Parliamentary (IPPG) Agreement of 1997 and went on unilaterally to appoint 19 of 22 Electoral Commission of Kenya (ECK) commissioners without consulting the other political parties. This was seen as a deliberate attempt to undermine the independence of the electoral commission. Secondly, a week before the elections Kibaki appointed six judges to the Electoral Court, evidence that he was preparing to stage-manage judicial resolution of any disputes that might arise. Given that despite the judicial reforms of 2003, 12 electoral petitions against the outcome of the 2002 parliamentary elections remained unresolved, and individuals whose victories had been challenged had served a full five years, Kibaki's tampering with the electoral court on the eve of a general election raised considerable suspicion.

\section{THE OUTCOME}

More than 30 political parties contested the elections. However, the only real players were Kibaki's Party of National Unity (PNU) and the two opposition parties - Odinga's ODM and its breakaway faction, Kalonzo's ODM Kenya. The NARC, Nyachae's Ford People, the Social Democratic Party, and the Kenya African Development Union (Kadu) were insignificant players.

Quite clearly the outcome of the elections indicated the electorate's determination to challenge what was perceived as Kibaki's failure to deliver on his 2002 promises and to end 29 years of political and economic rot. It was an unambiguous rejection of five years of Kibaki's and 24 years of Moi's rule (Moi had campaigned vigorously for Kibaki).

In six of the eight provinces the PNU was rejected outright. Twenty of his 30 Cabinet ministers, including his vice-president and ministers from his Central Province backyard, lost their parliamentary seats; Raila's ODM won 99 seats to Kibaki's 37 and dominated local authority elections in all but the Central and North Eastern provinces. This was both a total rejection of Kibaki and a vote for change, since change in the presidency was perceived as absolutely necessary to redress the historical imbalances noted above.

The results, according to many observers, were a foregone conclusion once Raila succeeded in stitching together a western alliance (Nyanza, Western and Rift Valley provinces) and the Coast Province. The ODM alliance was the old NARC alliance without the Central and Eastern provinces, Central Province having swapped places with the Rift Valley Province in the old alliance.

Interestingly, the pattern of voting has not changed much. The figures for 2007, as demonstrated in the three tables below, were not very different from the patterns in 1992, 1997 and 2002. The tables below prove the point. In 1992 Moi won with 36,9 per cent of the popular vote against a combined opposition tally 
of 63,1 per cent. In 1997 Moi won again, with a marginally improved 40 per cent against the combined opposition tally of 60 per cent. In 2002 Kibaki won with 62,8 per cent compared with Uhuru Kenyatta's 31 per cent. The 2007 figures seemed to have replicated these results.

In the political realignment that took place after the break up of NARC in 2005 Raila's ODM had the big three - Luo, Luhya, and Kalenjin - with the support of the Coast, the North Eastern, and Nairobi provinces. Kibaki's PNU had the Kikuyu backing from the Central Province, while the ODM Kenya had Ukambani in the Eastern Province.

Thus there is no way the PNU could have won the presidency. The parliamentary result speaks for itself, unless, of course, there was some sort of strategic voting pattern whereby those who voted for opposition candidates in the general election chose to vote differently when it came to presidential vote - a pattern never before seen in Kenya.

Table 1

1992 Presidential votes by province

\begin{tabular}{|l|l|l|l|l|l|}
\hline & Kibaki & Matiba & Moi & Odinga & Others \\
\hline & DP & FORD A & Kanu & FORD K & \\
\hline Nairobi & 69715 & 165553 & 62410 & 75888 & $*$ \\
\hline Coast & $18 \%$ & $44 \%$ & $16 \%$ & $20 \%$ & $2 \%$ \\
\hline & 32201 & 33399 & 188296 & 42796 & $*$ \\
\hline N Eastern & 3259 & $11 \%$ & $62 \%$ & $14 \%$ & $3 \%$ \\
\hline & $5 \%$ & $11 \%$ & 46420 & 5084 & $*$ \\
\hline Eastern & 392481 & 79436 & 290372 & 13673 & $*$ \\
\hline & $50 \%$ & $10 \%$ & $37 \%$ & $2 \%$ & $1 \%$ \\
\hline Central & 373147 & 630194 & 21918 & 10668 & $*$ \\
\hline & $35 \%$ & $60 \%$ & $2 \%$ & $1 \%$ & $2 \%$ \\
\hline Rift Valley & 98302 & 214727 & 981488 & 75465 & $*$ \\
\hline & $7 \%$ & $16 \%$ & $71 \%$ & $5 \%$ & $1 \%$ \\
\hline Western & 14404 & 214060 & 219187 & 98822 & $*$ \\
\hline & $2 \%$ & $38 \%$ & $39 \%$ & $17 \%$ & $4 \%$ \\
\hline Nyanza & 51988 & 10299 & 117554 & 581490 & $*$ \\
\hline & $6 \%$ & $1 \%$ & $15 \%$ & $75 \%$ & $3 \%$ \\
\hline Total & 1035507 & 1354856 & 1927 & 903886 & \\
\hline
\end{tabular}


Table 2

1997 General election vote by province

\begin{tabular}{|l|l|l|l|l|l|}
\hline & Moi & Kibaki & Raila & Kijana & Ngilu \\
\hline & Kanu & DP & NDP K & FORD K & SDP \\
\hline Nairobi & 75272 & 160124 & 59415 & 24971 & 39700 \\
\hline & $20,56 \%$ & $44 \%$ & $16,23 \%$ & $6,82 \%$ & $10,85 \%$ \\
\hline Coast & 229084 & 50540 & 22794 & 11156 & 37600 \\
\hline & $61,05 \%$ & $13,40 \%$ & $6,07 \%$ & $2,97 \%$ & $10,02 \%$ \\
\hline N Eastern & 46121 & 11741 & 210 & 4418 & 466 \\
\hline & $73,08 \%$ & $18,60 \%$ & $0,33 \%$ & $7,00 \%$ & $0,58 \%$ \\
\hline Eastern & 368801 & 296262 & 7755 & 7009 & 33250 \\
\hline & $35,87 \%$ & $28,81 \%$ & $0,75 \%$ & $0,68 \%$ & $32,35 \%$ \\
\hline Central & 55822 & 885382 & 6812 & 3067 & 29470 \\
\hline & $5,59 \%$ & $88,73 \%$ & $0,68 \%$ & $0,31 \%$ & $2,95 \%$ \\
\hline
\end{tabular}

\begin{tabular}{|l|l|l|l|l|l|}
\hline Rift Valley & 1140409 & 343529 & 36022 & 102178 & 11340 \\
\hline & $69 \%$ & $20,90 \%$ & $2,19 \%$ & $6,22 \%$ & $0,69 \%$ \\
\hline Western & 314669 & 9755 & 13458 & 338120 & 3429 \\
\hline & $44,67 \%$ & $1,38 \%$ & $1,91 \%$ & $48,00 \%$ & $0,49 \%$ \\
\hline Nyanza & 215923 & 138194 & 519259 & 14623 & 15300 \\
\hline & $23,53 \%$ & $15,05 \%$ & $56,55 \%$ & $1,59 \%$ & $1,57 \%$ \\
\hline Total & 2445801 & 1895527 & 665725 & 505542 & 46980 \\
\hline
\end{tabular}

Source: Ajulu 1998 
Table 3

2002 Presidential Election Results

Summary Per Province - Preliminary

\begin{tabular}{|c|c|c|c|c|c|c|c|}
\hline & $\begin{array}{l}\text { Registered } \\
\text { voters }\end{array}$ & $\begin{array}{c}\text { Kenyatta } \\
\text { Uhuru } \\
\text { Muigai }\end{array}$ & $\begin{array}{c}\text { Kibaki } \\
\text { Mwai }\end{array}$ & $\begin{array}{c}\text { Nyachae } \\
\text { Simeon }\end{array}$ & $\begin{array}{c}\text { Orengo } \\
\text { James } \\
\text { Aggrey }\end{array}$ & $\begin{array}{c}\text { Waweru } \\
\text { David } \\
\text { Ngethe }\end{array}$ & $\begin{array}{l}\text { Total } \\
\text { valid } \\
\text { votes }\end{array}$ \\
\hline & & Kanu & Narc & Ford-p & SDP & CCU & \\
\hline \multicolumn{8}{|l|}{ Province } \\
\hline \multirow[t]{2}{*}{ Nairobi } & 884135 & 75635 & 279709 & 8771 & 890 & 303 & 365308 \\
\hline & & $20,704 \%$ & $76,568 \%$ & $2,401 \%$ & $0,244 \%$ & $0,083 \%$ & \\
\hline \multirow[t]{2}{*}{ Coast } & 879741 & 109706 & 219409 & 11470 & 1430 & 790 & 342805 \\
\hline & & $32,002 \%$ & $64,004 \%$ & $3,346 \%$ & $0,417 \%$ & $0,230 \%$ & \\
\hline \multirow[t]{2}{*}{$\mathrm{N}$ Eastern } & 216336 & 79004 & 33348 & 4947 & 169 & 73 & 117541 \\
\hline & & $67,214 \%$ & $28,317 \%$ & $4,209 \%$ & $0,144 \%$ & $0,062 \%$ & \\
\hline \multirow[t]{2}{*}{ Eastern } & 1734209 & 233614 & 658913 & 7188 & 3116 & 1987 & 904818 \\
\hline & & $25,819 \%$ & $72,823 \%$ & $0,794 \%$ & $0,344 \%$ & $0,220 \%$ & \\
\hline \multirow[t]{2}{*}{ Central } & 1563084 & 300222 & 680386 & 4279 & 1383 & 1947 & 988217 \\
\hline & & $30,380 \%$ & $68,850 \%$ & $0,433 \%$ & $0,140 \%$ & $0,197 \%$ & \\
\hline \multirow[t]{2}{*}{ Rift Valley } & 2415555 & 734932 & 623343 & 35972 & 3740 & 1616 & 1399603 \\
\hline & & $52,510 \%$ & $44,537 \%$ & $2,570 \%$ & $0,267 \%$ & $0,115 \%$ & \\
\hline \multirow[t]{2}{*}{ Western } & 1202104 & 126483 & 468037 & 8295 & 3195 & 1545 & 607555 \\
\hline & & $20,818 \%$ & $77,036 \%$ & $1,365 \%$ & $0,526 \%$ & $0,254 \%$ & \\
\hline \multirow[t]{2}{*}{ Nyanza } & 1555968 & 63572 & 522121 & 227363 & 9630 & 1115 & 823801 \\
\hline & & $7,17 \%$ & $63,380 \%$ & $27,599 \%$ & $1,169 \%$ & $0,135 \%$ & \\
\hline $\begin{array}{l}\text { National } \\
\text { total }\end{array}$ & 10451150 & 1723168 & 3485266 & 308285 & 23553 & 9376 & 5549648 \\
\hline $\begin{array}{l}\% \text { votes } \\
\text { won }\end{array}$ & & $31,050 \%$ & $62,802 \%$ & $5,555 \%$ & $0,424 \%$ & $0,169 \%$ & \\
\hline
\end{tabular}

Source: Electoral Commission of Kenya December 2002 
The outcome of the 2007 elections was the result of changing alliances and a newfound confidence in the ballot box. I have argued elsewhere (Ajulu 2008) that for more than four decades Kenyans had been used to rigged elections, and had lost faith in electoral politics.

The historic 2002 general elections changed all this. The impact of the 2002 elections was a decisive shift in the old scenario and restored some faith and confidence in the ballot box. The Kenyan electorate became increasingly confident as the 2007 elections approached. The constitutional referendum of 2005, which had handed Kibaki a humiliating 'No' vote, seemed to have reinforced this confidence - the belief that the people could actually vote out unwanted leaders. And with this renewed confidence came the hope that popularly elected leaders would address the historical injustices revolving around ethnic tensions fostered by regional inequalities, economic marginalisation and unmitigated poverty.

\section{SO WHY SUCH VIOLENCE?}

How do we explain the violence of the reaction to Kibaki's illegitimate extension of his tenure? The anger seen in the aftermath of his swearing in stemmed from a widespread feeling of having been cheated out of change, the hope of which had brought people to the polling stations on 27 December in greater numbers than ever before in Kenya's electoral history.

For some the sense of frustration about the result ignited all the grievances of the past four decades in relation to poverty, the need for land reform, unemployment, perceived ethnic arrogance and other issues. While the nature of the violence shocked many observers and political analysts only the scale was unique - such ethnic confrontations have been part of political contestation ever since the country gained its independence.

One of the enduring legacies of Kenyan politics is the use of ethnicity as a medium of political mobilisation and contestation of resources. Although it was basically a creation of settler colonialism, after independence, for reasons I have analysed elsewhere in more detail (Ajulu 2001), ethnicity has become the most important and effective instrument of political mobilisation.

Historically political elites have mobilised and politicised ethnic or religious identities in order to achieve certain political and economic objectives. It must be pointed out, however, that such mobilisation only takes place in certain circumstances. In 'normal' conditions ethnic identity does not play an important role in the interaction between different groups and different ethnic groups have lived together in various parts of Kenya for decades without resorting to solving their differences through violence. Only at certain specific historical conjunctures does the need arise to mobilise ethnic bonds. The aim may be to defend the identity 
of a group from a perceived attack by other groups, to contest the distribution of resources, or simply to promote an already dominant group. Either way, the relationship between ethnic mobilisation and conflict is clear. At one end there may be no conflict at all, at the other the potential for conflict is enormous. Kenya has experienced four such conjunctures.

The first of these was the battle for power during the run up to the independence election in 1963 between the two parties of Kenya nationalism, Daniel arap Moi and Ronald Ngala's Kenya African Democratic Union (Kadu) and Jomo Kenyatta and Oginga Odinga's Kenya African National Union (Kanu. Kadu was the party of what Bennet (1957) called the 'alliance of the pastoralist tribes' - Kalenjin, Masai, Turkana, Samburu' and the Giriama of the Coast and sections of the Luhyia of Western Kenya - while Kanu had the support of the two major ethnic groups - the Luo and Kikuyu.

So intense was the battle that the minority parties opted for ethnic separatism fearing that the dominant ethnicities - the Luo and Kikuyu - would run roughshod over the minorities. At the centre of these fears were post-colonial land dispensation and the distribution of other resources - jobs, infrastructure, and so on. It was in these circumstances that a federalist dispensation ('majimboism') was imposed on Kenya by the Lancaster Agreement that ushered in independence.

Federalism however was not Kadu's creation. It had its origins in 1954 with the formation of the whites-only Federal Independent Party (FIP), which had sought to protect the 'White Highlands' from African control by adopting a federal platform. In 1958 the FIP became the Progressive Local Government Party (PLGP): the rhetoric had changed but the objectives remained the same. The party advocated strong local governments, with powers over local taxation and expenditure. Kadu only adopted the 'majimbo' idea in 1961, and only when it had become clear that, together with its allies, Michael Blundell's New Kenya Party (NKP) and the Kenya Indian Congress (KIC), which then controlled the transition government, were unlikely to win the 1963 election and assume control of an independent unitary state. Majimboism was launched under the slogan 'Regionalism or Civil War' (Sanger \& Nottingham 1964).

It was in these circumstances that the Kalenjin political elite began mobilising on a platform of Kalenjin ethnicity. William Murgor, then parliamentary secretary to the Defence and Internal Security department in the transitional government, invited fellow Kalenjin tribesmen to sharpen their spears and wait for the sound of his whistle for the start of war to drive non-Kalenjins out of Rift Valley. Arap Moi, then chairman of Kadu, vowed to shed his blood to ensure that regionalism was written into the independence constitution (Athieno-Odhiambo 1998).

Thus, from 1961, ethnic clashes swept through the Rift Valley Province. The Kikuyu, Luhyia and other ethnic groups which had lived in the area for years 
were labelled foreigners. Their houses were burnt and many became refugees - a situation that was to be repeated in the elections of 2002 and 2007. In the Coast Province Kadu's Sammy Omari popularised the slogans Wabarra Kwao (Up country people back to their own homelands!) and Kila mtu Kwao (Every person to his or her own homeland!). These slogans had, of course, to be backed up by violence.

The second bout of ethnic mobilisation came in the wake of the assassination of Tom Mboya in 1969. As stated above Mboya was the victim of internal rivalry within the ruling Kanu party to succeed Kenyatta. His assassination, however, came at a time when a majority of ethnic groups increasingly resented the consolidation of economic and political power by the hegemonic Kikuyu ruling elite and thus threatened to unite the Luo and other ethnic groups behind Odinga against the Kikuyu. The possibility of a resurgence in Odinga's political fortunes struck panic within the Kiambu coalition, resulting in the oathing campaign detailed above. ${ }^{3}$

It was not the small hegemonic elite that was threatened by the crisis, which it had brought upon itself; rather, its members argued, the entire Kikuyu ethnic group was under threat and must take the oath in readiness to defend the House of Mumbi, the eponymous founder of the Kikuyu tribe. As Ngunyi (1993) puts it:

... to protect its stakes and maintain the regime's inner stability ... the 'Family' quickly constituted a Kikuyu brigade charged with the tacit responsibility of mobilizing the entire Kikuyu community to protect the 'motherland' against the 'enemy' ... The brigade was also responsible for administering to the community an oath of loyalty to the House of Mumbi and vowing by the oath to ensure that the Presidency never leaves the 'tribe'.

The third use of ethnic mobilisation came in the wake of the assassination of JM in 1975, an event that was to divide the Kikuyu ethnic group down the middle, isolating Kiambu from Muranga, Nyeri, and the 'Diaspora' Kikuyu. Now the context of ethnic mobilisation changed. This time round, the Kiambu Kikuyu took oath to prevent the piki piki (the presidential motor cycle outriders) from crossing the Chania River, the boundary between Kiambu and the neighbouring Kikuyu District of Muranga.

The reintroduction of competitive elections in 1991 was the fourth time ethnic mobilisation was used and marked a return of ethnic conflict to the Rift Valley Province. Once again it was the old minority coalition - the Kalenjin, Maasai

3 See, for example, Ngunyi (1993). 
Turkana and Samburu (Kamatusa), now under the umbrella of Kanu, which resorted to ethnic separatism, publicly calling on their brethren to commit acts of violence against ethnic groups which were perceived not to support the party.

In the run up to the 1992 elections the Nakuru Kanu district chairperson, Wilson Leitich, is reported to have instructed Kanu youth wingers to patrol the streets with knives, ready to chop off the fingers of anyone who showed the twofinger multiparty salute. He also instructed his youth wingers to confiscate trading licences from multiparty advocates and take them to the Kanu office (Africa Watch 1991, pp 49-50; Daily Nation 10 June 1990).

As in the early 1960s politicians instituted 'ethnic cleansing' in Rift Valley and throughout the bordering areas, leading to the removal of what they called Madoadoa (islands of non-Kalenjin groups). Their ultimate objective was stated bluntly: '... with the introduction of multi-party system the survival of the smaller ethnic groups is threatened and the only way to safeguard their interests was through this type of ethnic separatism' (Kenya Times 20 May 1993).

In the run up to the 1997 election a savage war of annihilation broke out in the Coast Province at a time when Kanu had lost the political initiative to a section of the opposition and its allies within the National Convention Assembly and it increasingly appeared that constitutional reform would be instituted which would 'level the playing field'. Violence erupted in the province, with attacks on Likoni police station on Mombasa mainland. It is widely held that once again persons high up in the government were responsible for organising, funding, and orchestrating the violence.

\section{CONCLUSION}

The outburst of violence and ethnic mobilisation that followed the 2007 election can be set against this background. Kibaki's theft of the election came at a point when a majority of ethnic groups increasingly resented the consolidation of economic and political power by the hegemonic Kikuyu ruling elite.

Kibaki's inner cabal (the Mount Kenya Mafia), like that of Kenyatta's 'Kiambu Bourgeoisie' or the 'Family' 38 years earlier, came exclusively from the Central Province, straddled economic and political power, dominated the economic, bureaucratic, diplomatic and corporate sectors, and displayed absolute arrogance in the use of its powers. Voters believed that a change in the presidency was absolutely necessary to redress the historical imbalances referred to above.

The recent upheavals in Kenya teach us a number of lessons. One is that elections cannot be separated from the existing political situation. A country rent by sharp divisions over poverty and the distribution of power and structured 
by battles over resources cannot possibly hold free and fair election however independent their electoral institutions.

Finally, a government which fails to include all sectors of society is likely to go the Kenyan way. Historically Kenya has managed to paper over the cracks but we now understand that beneath the semblance of stability lie serious problems which must be addressed urgently if we are not to see a return of this type of violence at the next elections.

\section{- REFERENCES -}

Africa Watch. 1991. Kenya: Taking Liberties. New York.

1993. Divide and Rule: State Sponsored Ethnic Violence in Kenya. New York and Washington.

Ajulu, R. 1993. 'The 1992 Kenya General Elections: A Preliminary Assessment'. Review of African Political Economy 56.

1998. 'Kenya's Democracy Experiment: The 1997 Elections'. Review of African Political Economy 76.

2001. 'Kenya: One Step Forward, Three Steps Back'. Review of African Political Economy 28(88).

2008. Kenya's 2007 General Elections: Anatomy of an Electoral Crisis. Midrand: Institute of Global Dialogue.

Atieno-Odhiambo, E. 1993. 'The Agrarian Question, Ethnicity and Politics in Kenya, 1955-1993. Paper presented at a conference on Ethnicity, Identity and Nationalism in South Africa: Comparative Perspectives, Rhodes University, 20-24 April.

1998. 'Hegemonic Enterprises and Instrumentalities of Survival: Ethnicity and democracy in Kenya'. Paper presented at the Africa Philosophy Colloquium: Reconceptualising Africa's Governance, University of Louisville, Kentucky, 2-4 April.

Bennet, G. 1957. Kenya, A political History: The Colonial Period. Oxford: Oxford University Press.

Gertzel, C J, M Goldschmidt \& D Rothschild. 1969. Government and Politics in Kenya. Nairobi: East African Publishing House.

Goldsworthy, D. 1982. Tom Mboya, The Man Kenya Wanted to Forget. London: Heinemann.

Gibbon, P (ed). 1995. Markets, Civil Society and Democracy in Kenya. Uppsala: Nordiska Afrikainstitutet,

Kanyinga, K. 1994. 'Ethnicity, Patronage and Class in Local Arena: High and Low Politics in Kiambu, Kenya, 1982-92'. In P Gibbon (ed). The New Local Politics 
in East Africa, Research Report no 95. Uppsala: Scandanavian Institute of African Studies.

Karimi, J \& P Ochieng. 1980. The Kenyatta Succession. Nairobi: TransAfrica Books Distributors.

Mueller, S. 1984. 'Government and Opposition in Kenya, 1966-1969'. Journal of Modern African Studies 22(3).

Muigai, G. 1995. 'Ethnicity and the Renewal of Competitive Politics in Kenya'. in H. Glickman (1995) (ed), Ethnic Conflict and Democratization in Africa. Atlanta: The African Studies Association Press.

Mwangi, O G. 2008. 'Political Corruption, Party Financing and Democracy in Kenya'. Journal of Modern African Studies 46(2).

Njonjo, A. 1977. 'The Africanisation of the "White Highlands": AStudy in Agrarian

Class Struggles in Kenya'. Unpublished PhD thesis, Princeton University.

Ngunyi, M C. 1993. Interpreting Political Liberalism in Kenya. Copenhagen:

Scandinavian Institute of African Affairs and Centre for Development Research.

Nyong'o, P A. 1989. 'State and Society in Kenya: The Disintegration of the Nationalist Coalition and the Rise of Presidential Authoritarianism, 196378'. African Affairs 88 (351).

Ochieng, W R. 1995. 'The Kenyatta Era: Structural and Political Changes'. In B A Ogot \& W R Ochieng (eds). Decolonization and Political Independence in Kenya. London, Nairobi and Athens, Ohio: James Currey, East African Educational Publishers and Ohio University Press.

Odinga, J O. 1966. Not Yet Uhuru, London: Heinemann.

Oyugi, W. 1997. 'Ethnicity in the Electoral Process: The 1992 General Elections in Kenya'. African Journal of Political Science 2(1).

Throup, D. 1989. 'The Construction and Deconstruction of the Kenyan State'. In M Schartzberg (ed). The Political Economy of Kenya. New York: Praeger. 1993. 'Elections and Political Legitimacy in Kenya'. Africa 63(3).

National Christian Council of Kenya (NCCK). 1992. The Cursed Arrow: Contemporary Report on the Politicized Clashes in Rift Valley, Nyanza, and Western Provinces. Nairobi. 1992. Report on Ethnic Clashes: Task Force Appointed by Inter-Parties Symposium. Nairobi.

\section{Newspapers}

Kenya Times 20 May 1993

Daily Nation 10 June 1990 